\title{
Mineral Resources of
}

the Mount Baldy

\section{Primitive Area, Arizona}

GEOLOGICAL SURVEY BULLETIN 1230-H

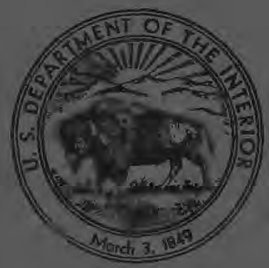





\section{Mineral Resources of}

\section{the Mount Baldy}

\section{Primitive Area, Arizona}

By TOMMY L. FINNELL and C. GILBERT BOWLES, U.S. Geological Survey, and JOHN H. SOULE, U.S. BuREAU OF MiNes

STUDIES RELATED TO WILDERNESS

GE OLOGICAL S URVEY B U L LE T I N 1230-H

An evaluation of the mineral potential of part of the White Mountains

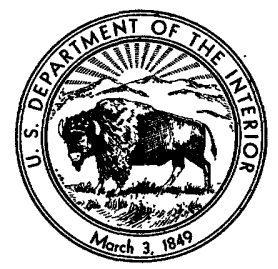




\section{UNITED STATES DEPARTMENT OF THE INTERIOR}

STEWART L. UDALL, Secretary

\section{GEOLOGICAL SURVEY}

William T. Pecora, Director 


\section{STUDIES RELATED TO WILDERNESS}

The Wilderness Act (Public Law 88-577, Sept. 3, 1964) and the Conference Report on Senate bill 4, 88th Congress, direct the U.S. Geological Survey and the U.S. Bureau of Mines to make mineral surveys of wilderness and primitive areas. Areas officially designated as "wilderness," "wild," or "canoe," when the Act was passed, were incorporated into the National Wilderness Preservation System. Areas classed as "primitive" were not included in the Wilderness System, but the Act provided that each primitive area should be studied for its suitability for incorporation into the Wilderness System. The mineral surveys constitute one aspect of the suitability study. This bulletin reports the results of a mineral survey in the Mount Baldy primitive area, Arizona. The area discussed in the report corresponds to the area under consideration for wilderness status. It is not identical with the Mount Baldy Primitive Area as defined because modifications of the boundary have been proposed for the area to be considered for wilderness status. The area that was studied is referred to as the Mount Baldy primitive area.

This bulletin is one of a series of similar reports on primitive areas. 



\section{CONTENTS}

Page

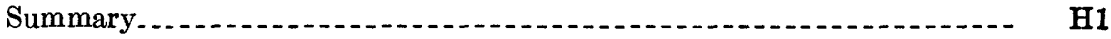

Geology and mineral resources, by Tommy L. Finnell and C. Gilbert Bowles

Location and geography

Relation to Fort Apache Indian

Pelation to Fort Apache Indian Primitive Area.....................

Previous studies

Present study

Descriptive geology

Upper Tertiary volcanic rocks...........

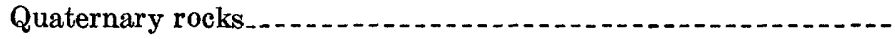

Strueture

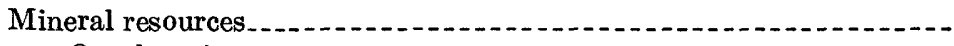

Ore deposits.

Construction material

Other mineral commodities............................ 11

Economic appraisal, by John H. Soulé. _. _ _

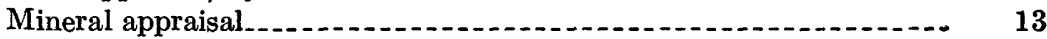

References cited.-...

\section{ILLUSTRATIONS}

Figure 1. Index map of Arizona

2. Index map of primitive area

3. Index map showing relation of Fort Apache Indian Primitive Area to the Mount Baldy primitive area................

4. Reconnaissance geologic map of the Mount Baldy primitive area

Page

H2

\section{TABLE}

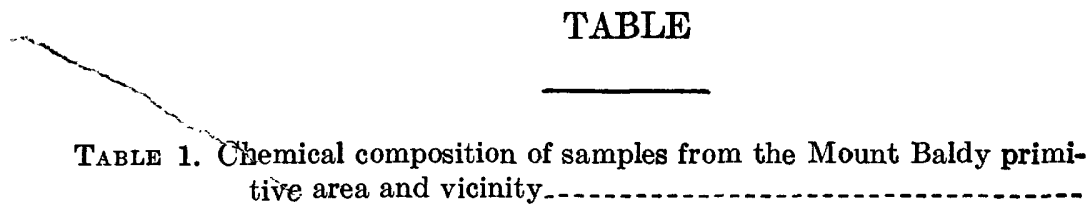


<smiles>CCC</smiles> 


\title{
STUDIES RELATED TO WILDERNESS
}

\section{MINERAL RESOURGES OF THE MOUNT BALDY PRIMITIVE AREA, ARIZONA}

\author{
By Tommy L. Finnell and C. Ginbert Bowles, U.S. Geological \\ Survey, and ЈонN H. SouLí, U.S. Bureau of Mines
}

\section{SUMMARY}

The Mount Baldy primitive area occupies an area of about 7,400 acres in the White Mountains of east-central Arizona in the Apache National Forest: The area is apparently barren of mineral deposits. No mineral deposits, mining claims, or concentrations of trace metals were recognized within the primitive area during the investigations of the U.S. Geological Survey and the U.S. Bureau of Mines. No oil test holes have been drilled within the area; holes drilled about s5 miles north of the area were not produetive.

The Mount Baldy primitive area is underlain by about 3,500 feet of volcanic flows and as much as $\mathbf{4 5 0}$ feet of glacial drift. The volcanic rocks are mainly andesite porphyry, basalt, and basaltic scoria and tuff beds. The glacial drift consists mainly of rock fragments derived from the volcanic rocks.

Representative samples of most of the bedrock units and of sediments from the main streams draining the area were analyzed by semiquantitative spectrographic and chemical methods. The metal content of all the samples is low, and the possibility of commercial deposits of metallic ores in the area seems remote.

A small cinder cone in the north part of the area might yield material suitable for road metal, but its small size and inaccessibility as compared with many other cinder cones in the region lessen its potential value.

The Coconino Sandstone, a potential reservoir for petroleum and natural gas, may be present at depth beneath the White Mountains; but the existence of structural traps is highly conjectural.

Rocks of the type that yield bleaching clay are not in the primitive area. If coal is beneath the volcanic rocks, it is probably of low grade, thin, and too far below the surface for exploitation.

\section{GEOLOGY AND MINERAL RESOURCES}

By Tomux L. Finnel. and C. Gilbert Bowles, U.S. Geological Survey

\section{LOCATION AND GEOGRAPHY}

The Mount Baldy primitive area is in the White Mountains of castcentral Arizona (fig. 1). The area is roughly triangular and consists 


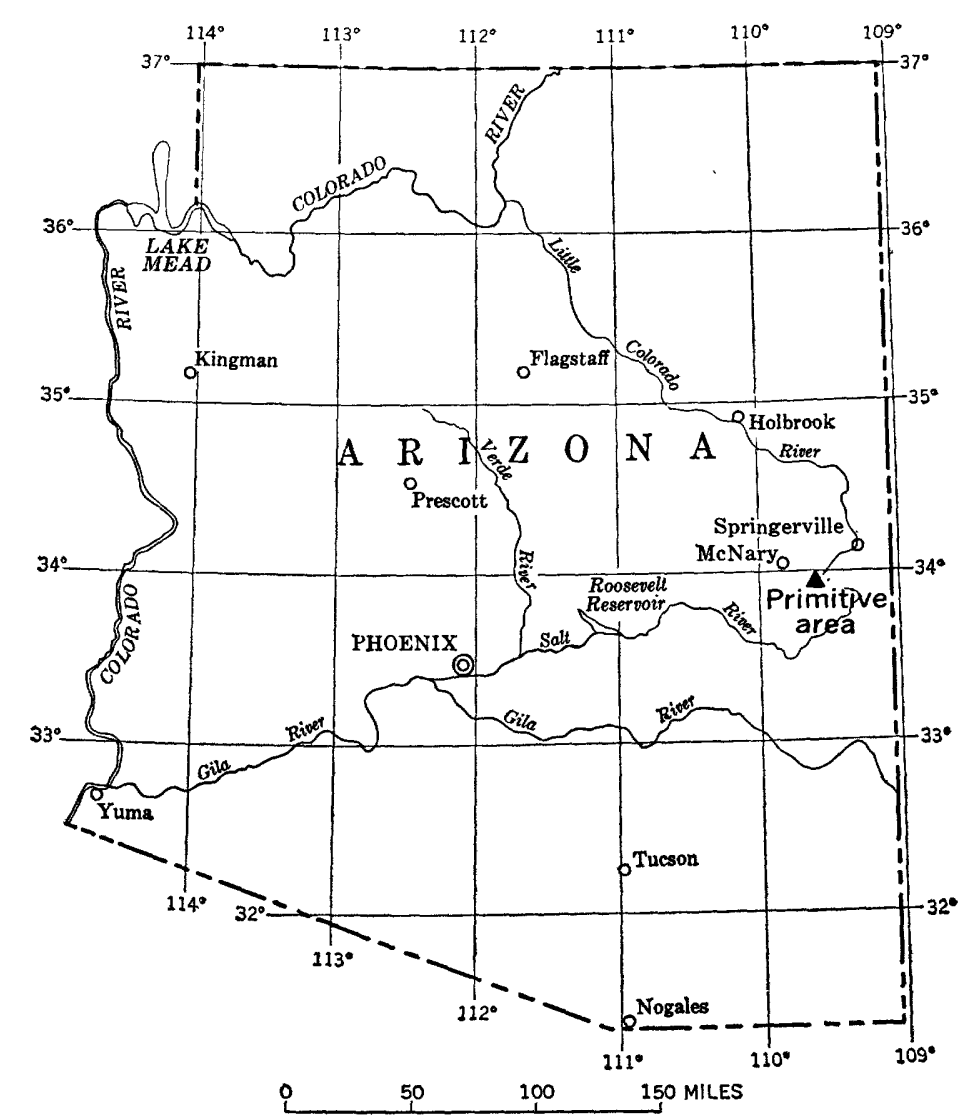

Frgure 1.-Location of Mount Baldy primitive area.

of about 7,400 acres in south-central Apache County. It is drained by northeast-flowing tributaries of the Little Colorado River. The south, west, and northwest boundaries of the area roughly follow ridges marking the drainage divide with south- and west-flowing tributaries of the Salt River. The ridges are rounded, with some sharp crests, and are interrupted by steep bluffs, saddles, and knolls. Valleys in the primitive area have gently sloping floors and moderately steep walls which in places include cliffs as much as 100 feet high. Altitudes within the area range from about 9,200 to 11,550 feet above sea level. Baldy Peak, the highest point in the White Mountains, is about a quarter of a mile south of the primitive area and has an altitude of 11,590 feet.

Most of the slopes and ridges are covered by forest; mixed stands of fir, pine, and aspen extend up to an altitude of about 10,500 feet, 
and spruce extends from there to the summit. Meadows along the valley floors merge locally with grassy slopes that in places continue several hundred feet up the valley walls. The summit ridge of Mount Baldy is nearly devoid of trees, and the windswept west slope is sparsely covered with grass.

The area may be reached by automobile at two places along its northeastern boundary (fig. 2) by following dirt roads that lead from

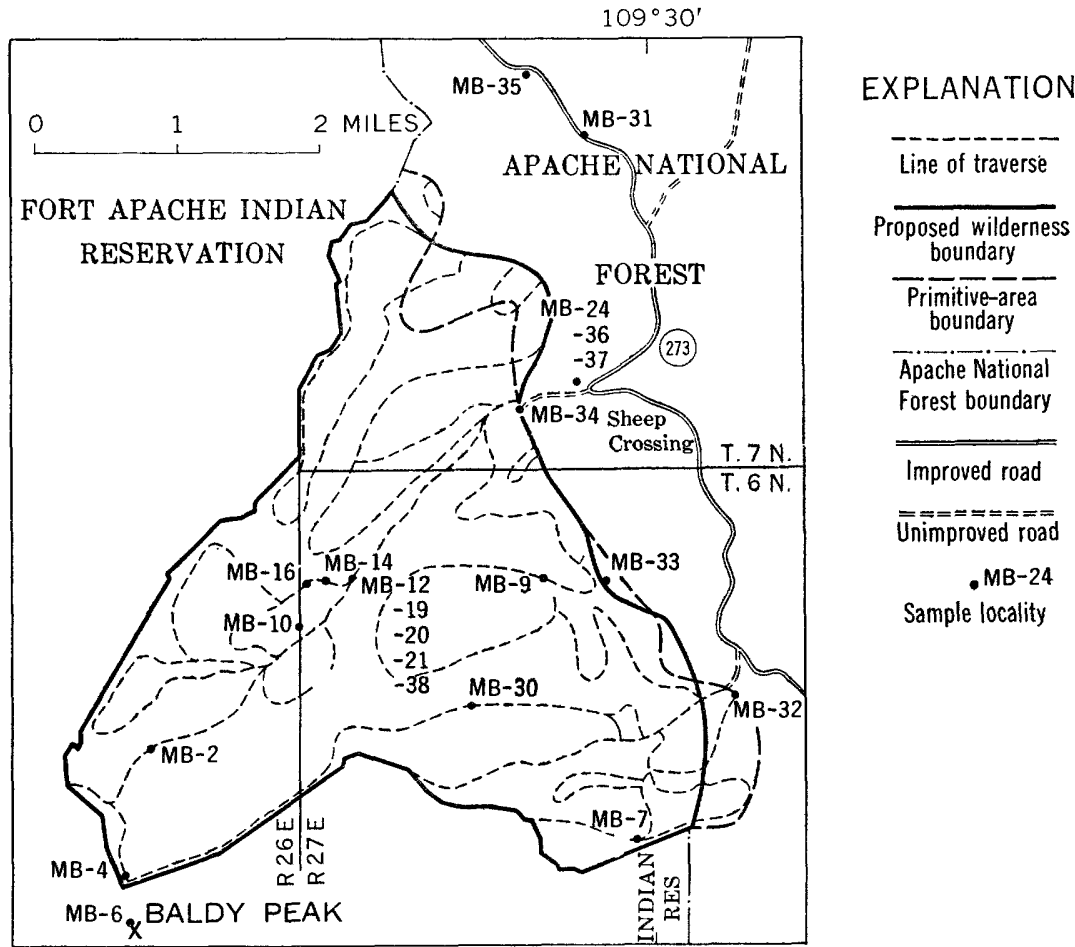

FrguRE 2.-Existing primitive area, proposed wilderness boundary, principal routes of access, location of geologic traverses, and sample localities.

State Highway 273, a graded road. This road in turn is reached from State Highway 73 about 20 miles east from McNary or about 13 miles south and west from Springerville. Trails from the ends of the roads provide access to the primitive area.

The Mount Baldy primitive area is in the Apache National Forest and adjoins the Fort Apache Indian Reservation. It is largely in T. 6 N., R. 26 and 27 E., and T. 7 N., R. 27 E. The area described in this report does not coincide with the Mount Baldy primitive area but includes small additional areas to be included in the proposed wilderness. 


\section{RELATION TO FORT APACHE INDIAN PRIMITIVE AREA}

An area of 7,400 acres adjoining the Mount Baldy primitive area (fig. 3) on the west and including the summit of Mount Baldy is at present a primitive area of the White Mountain Apache Tribe of

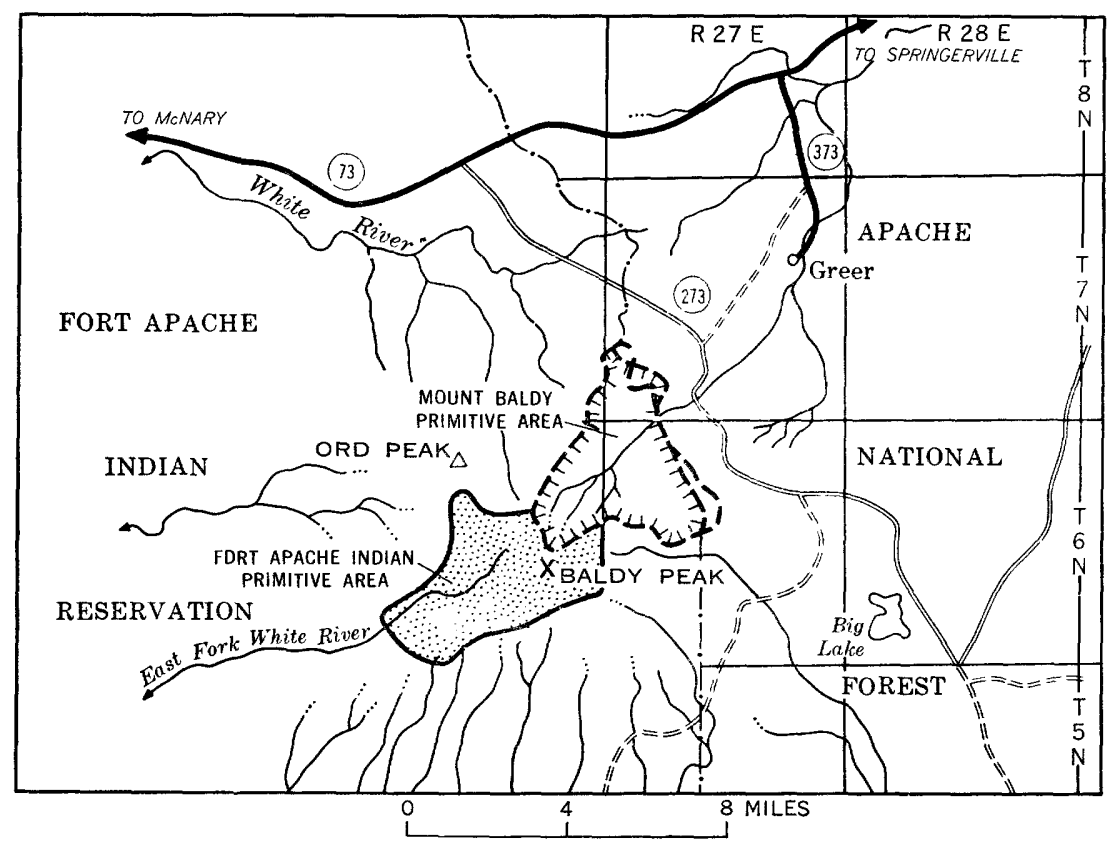

Figure 3.-Relation of Fort Apache Indian Primitive Area to the Mount Baldy primitive area. Approximate boundary of Mount Baldy primitive area, dashed line; proposed boundary of Mount Baldy Wilderness Area, hachured line.

the Fort Apache Indian Reservation. By resolution 66-20 of the Tribal Council of this tribe dated January 13, 1966, this area was declared a primitive area for a 5-year period ending December 31,1970 , with provision that before 1970 "the Tribal Council will review the land use requirements of the Fort Apache Indian Reservation and make a final determination on a permanent primitive area."

The Fort Apache Indian Primitive Area is not treated in this report but is believed to be generally similar in its geology and mineral resources to the Mount Baldy primitive area.

\section{PREVIOUS STUDIES}

Prior to the present study, the geology of the Mount Baldy primitive area was not well known. The general structure and lithology of the White Mountains were described by Gilbert (1875), and brief 
reconnaissance trips into the mountains were made by Reagan (1903) and Darton (1925). Gross geologic features of the primitive area are shown on the geologic map of Navajo and Apache Counties, Ariz. (Wilson and others, 1960). The scanty reconnaissance data and knowledge of nearby areas suggested that volcanic cinders and scoria suitable for construction materials were the only economic mineral resources that might be expected within the area.

\section{PRESENT STUDY}

The field investigation of the Mount Baldy primitive area was made in May 1966. A reconnaissance geologic map (fig. 4) was made as a basis for evaluating the mineral potential of the area from traverse observations and aerial photographs. Visibility on the ground is limited by dense forest, and at the time of study snow concealed most of the ground above 10,000 feet on the north- and east-facing slopes.

Samples were collected from the principal bedrock units and from sediments of the main streams draining the area and were analyzed spectrographically.

\section{DESCRIPTIVE GEOLOGY}

The Mount Baldy primitive area is underlain by a thick sequence of upper Tertiary and Quaternary volcanic rocks (fig. 4). These rocks consist of three main units-an older basaltic sequence, a middle andesitic sequence, and younger basalt flows. The rocks are mainly volcanic flows but include some basaltic scoria and agglomerate and two connected andesite dikes. 'The only sedimentary rocks in the area are thin conglomerate beds in the older basaltic sequence and poorly consolidated glacial drift. The older basalt flows dip steeply northeastward; the andesite flows dip gently northeast to east; the younger basalt flows are nearly horizontal.

\section{UPPER TERTIARY VOLCANIG ROGKS}

The oldest rocks exposed in the Mount Baldy primitive area are a sequence of basalt flows and scoria and interbedded fragmental basaltic tuff and conglomerate. These rocks probably are correlative with the lower part of a basaltic unit about 16 miles to the east, which Wrucke (1961) considered to be at least partly Tertiary in age, because they intertongue with a sedimentary formation that is similar to the Chuska Sandstone of Pliocene(?) age.

The basalts crop out in the upper valley of the West Fork of the Little Colorado River, but they presumably underlie much of the area at depth. They are generally poorly exposed but are well exposed at 
the West Fork in the vicinity of section $A-A^{\prime}$ (fig. 4). Distribution and dip of the flows indicate a thickness of more than 2,000 feet.

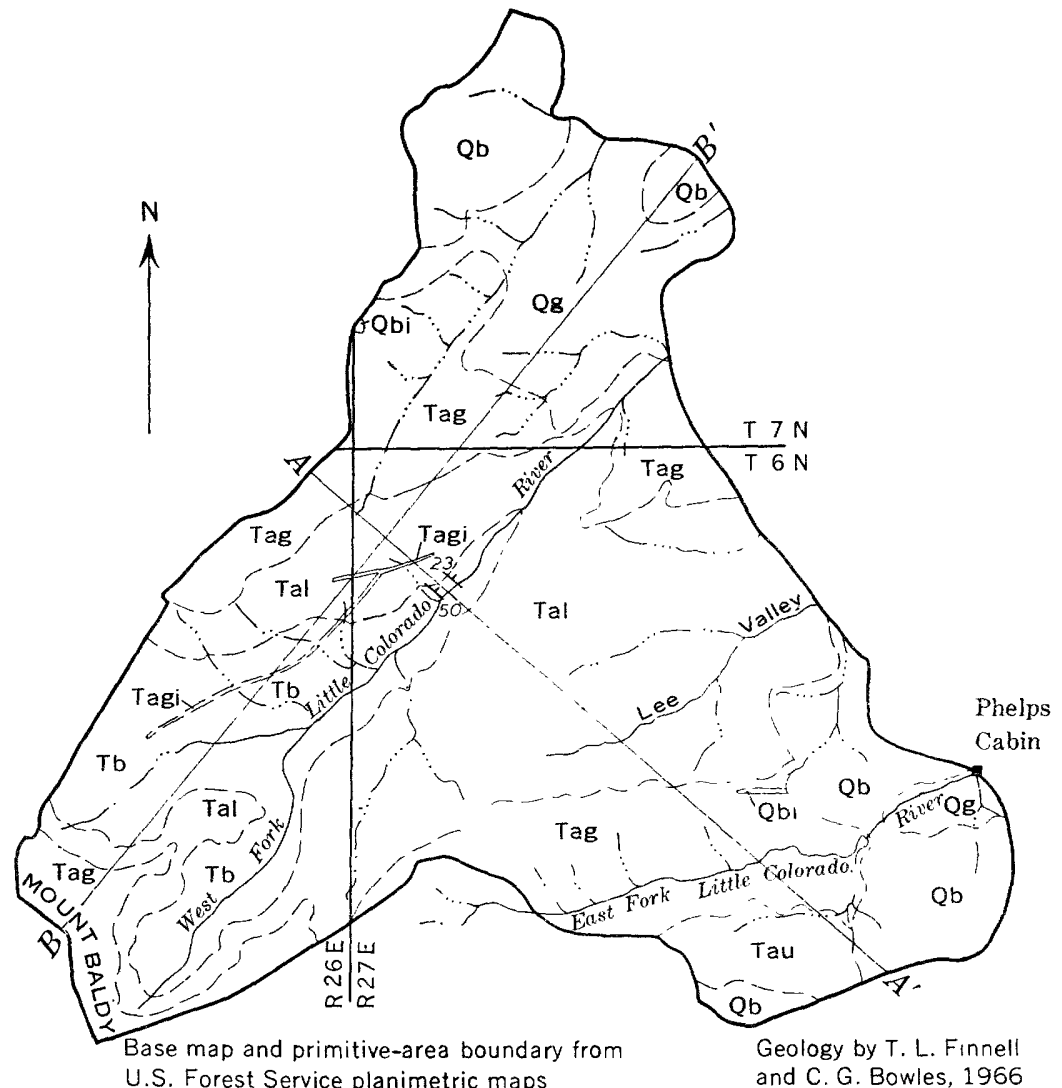

BALDYX

U.S. Forest Service planimetric maps

and C. G. Bowles, 1966

PEAK

(SUMMIT)
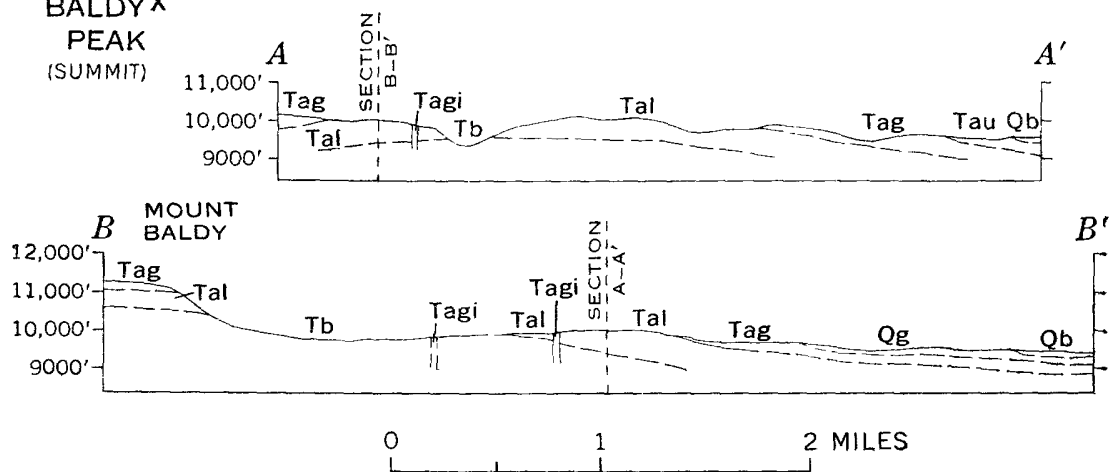

FIGURE 4.-Reconnaissance geologic map of the Mount Baldy primitive area, Arizona. 
The basalts are dark gray and dense to vesicular. The vesicular parts generally are weathered reddish brown. The dense variety locally has numerous closely spaced partings that impart a sheeted appearance to the rock. Olivine phenocrysts as much as an eighth of an inch long are common in the dense basalt. Much of the olivine is altered to a conspicuous redish-brown mineral.

\section{EXPLANATION}

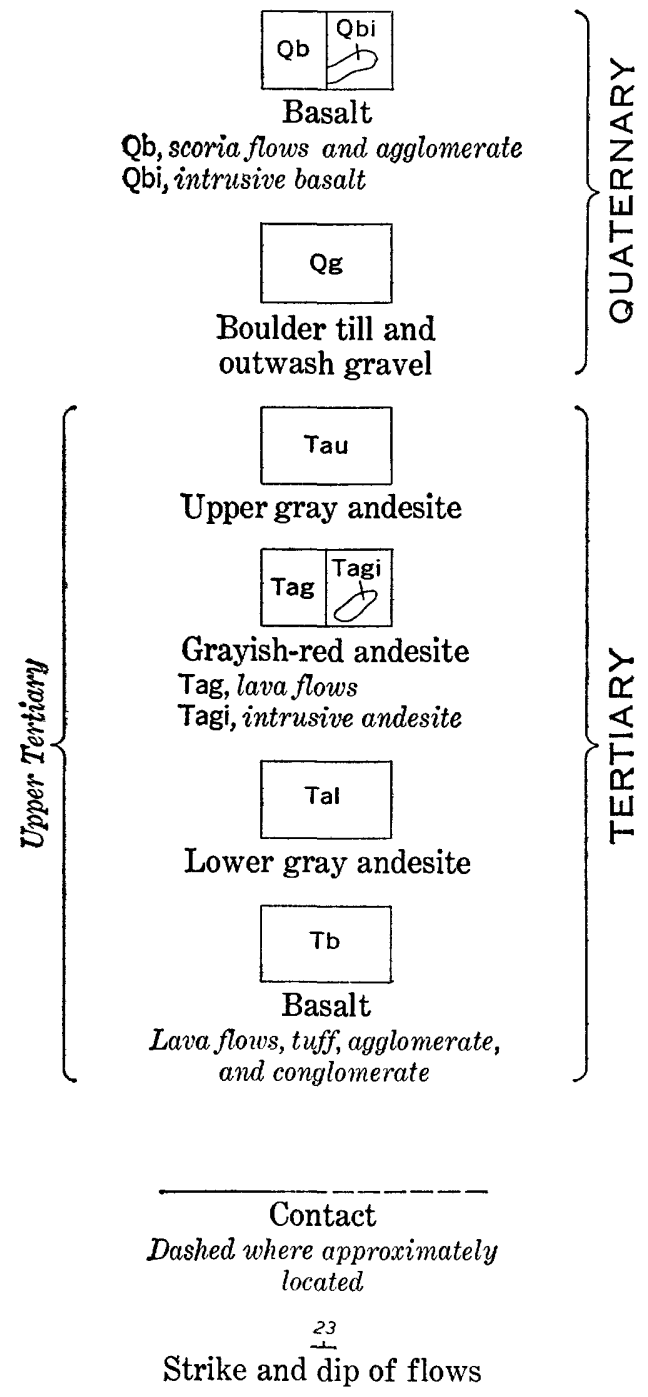

FIgUre 4.-Continued. 
The vesicular basalts grade along the strike into scoria beds and reddish brown basaltic tuff. Conglomerate beds consisting of rounded basalt pebbles and cobbles in a matrix of volcanic debris poorly cemented with chalcedony are interbedded both with the basalt flows and the tuffs. They are 1 to 6 feet thick and are sparsely scattered through the sequence.

All these rocks were tilted as much as $40^{\circ}$ from the horizontal, and their upturned edges were beveled by erosion before they were buried under thick flows of andesite.

Andesite flows that overlie the older basalts are the most widespread rocks in the Mount Baldy area. They are divided into three groups consisting (in ascending order) of the lower gray andesite, the grayish-red andesite, and the upper gray andesite. Distribution of these groups outlines part of a simple dome that may be of structural origin. The andesites have a total thickness of about 1,350 feet.

Flows of the lower gray andesite unit are predominantly light gray to medium gray, weathering to a slightly lighter gray, although some flows in Lee Valley are pale reddish brown. Most of the flows are porphyritic, containing as much as 30 percent plagioclase feldspar phenocrysts as much as three-eighths of an inch long and a few hornblende crystals about a quarter of an inch long. The matrix is fine grained and peppered with tiny biotite flakes. Locally, a few quartz phenocrysts are present.

Vesicular zones a few feet thick characterize the tops of some flows and are the chief basis for distinguishing the separate flows. Individual flows range from 50 to 150 feet in thickness, and the unit as a whole ranges from 400 to 675 feet in thickness.

The contact of the unit with the overlying grayish-red andesite is generally covered by soil and rubble but seems to be conformable where it can be observed.

The grayish-red andesite unit forms bold outcrops and cliffs that weather reddish brown to dark brown and to rounded but rough surfaces. The rock is porphyritic, containing 25 to 40 percent of plagioclase phenocrysts as much as half an inch long and biotite crystals as much as a quarter of an inch across. The matrix is fine grained and pale grayish red, grading locally to reddish brown. Joints in the unit are partly coated with brown limonite and residual magnetite. Individual flows in the unit are poorly defined and can be distinguished only by thin and discontinuous zones of vesicles at their tops. The unit is as much as 450 feet thick. It forms the summit of Mount Baldy.

The contact with the upper gray andesite is concealed by surficial deposits but is near the edge of a bench below the slopes formed by 
the upper gray andesite. A vesicular zone on the north side of the valley of the East Fork of the Little Colorado River probably lies near the top of the grayish-red andesite, but there it is overlain unconformably by Quaternary basalt.

Andesite in a branching dike northwest of the West Fork of The Little Colorado Riber is classed as grayish-red andesite. The dike cuts both the lower gray andesite and the older basalts and contains inclusions of the lower gray andesite.

The upper gray andesite unit is poorly exposed and forms moderately steep slopes alternating with sloping benches on the tops of flows. The unit is characterized by a light-gray to medium-gray color. The rock is porphyritic, containing 15 to 25 percent of plagioclase phenocrysts and some hornblende crystals. The vesicular parts contain few phenocrysts. The matrix is very fine grained, almost glassy in appearance. Individual flows are 50 to 75 feet thick and have vesicular tops, and the unit as a whole is at least 230 feet thick. It is overlain unconformably by Quaternary basalt.

\section{QUATERNARY ROCKS}

Glacial drift rests on eroded grayish-red andesite north of the West Fork. The drift is weakly consolidated and forms rounded slopes covered by soil and studded with boulders as much as 15 feet in diameter. The boulders are a heterogeneous collection of rocks derived mainly from the older basalts and andesites, but boulders or perlite porphyry (feldspar phenocrysts in a matrix of light-gray devitrified glass) and vitrophyre (feldspar phenocrysts in a matrix of black glass) are present locally. Boulders of the vitrophyre near the summit of Mount Baldy indicate that glassy porphyry once lay above the andesites. The drift may be as much as 450 feet thick.

The glacial drift is poorly exposed in the area, but the outwash deposits exposed in railroad cuts at Sheep Crossing and in the highway cut at sample locality MB-31 (fig. 2) clearly show the poor sorting, indistinct bedding, and striated stones that are typical of glacial deposits. In places the glacial drift is overlain by flows of Quaternary basalt.

Bouldery gravel deposits on valley walls, valley floors, and on some ridge saddles were probably deposited there by glaciers. Melton (1961) considered the older glacial drift to be of early or middle Pleistocene age (pre-Wisconsin) and the moraines on the valley floors to be of late Pleistocene age (Wisconsin).

Quaternary basalt occurs in patches along the northeast side of the Mount Baldy primitive area, where it lies on irregular surfaces cut over glacial drift and earlier volcanic rocks. The unit is as much as 
250 feet thick and includes basalt flows, scoria beds, agglomerate, a dike, and a small plug.

The basalt flows are dark gray and dense to vesicular and contain olivine phenocrysts as much as an eighth of an inch long. Some of the olivine is altered to a reddish-brown mineral. The matrix is fine grained and contains tiny laths of feldspar. The basalt forms gentle to moderately steep slopes and some cliffs, as much as 50 feet high. Some of the flows exhibit columnar jointing locally, and the basalt has numerous closely spaced partings that give the rock a sheeted appearance. The vesicular tops of flows form benches that merge upward into gentle slopes underlain by scoria beds.

The scoria beds and agglomerate are aggregates of vesicular basalt bombs that range from $1 / 4$ inch to 12 inches in diameter and that weather reddish brown. They probably were extruded from local vents and deposited in thin sheets on a surface of low relief and then were reworked slightly by running water.

A conical hill about 150 feet high, about three-quarters of a mile south-southwest of the north corner of the area, is composed of scoria fragments and may be an eroded cinder cone.

Recent alluvial deposits of silt, sand, and gravel are in channels and on flood plains of all the main streams in the primitive area.

\section{STRUCTURE}

The rocks of the primitive area are only slightly deformed. The basalts of Tertiary age were tilted and partly eroded before they were covered by andesite flows. The basalt flows strike northwest; and although they locally dip as much as $55^{\circ} \mathrm{NE}$., their average dip is $39^{\circ} \mathrm{NE}$.

The only faults observed in the area are small and are not shown on the map. These are a series of closely spaced vertical faults that trend northwest. They displace conglomerate of the Tertiary basalt sequence about 10 feet downward on the southwest side of the fault zone.

The andesite flows form a segment of a broad dome that crests near the summit of Mount Baldy. The dip to the northeast averages about $4^{\circ}$, but locally it steepens to $15^{\circ}$. Apparent dips indicated in section $A-A^{\prime}$ (fig. 4) are about $8^{\circ} \mathrm{NW}$. at the northwest end of the section and about $8^{\circ} \mathrm{SE}$. at the southeast end. The dips in the andesites may be entirely initial dips that reflect the attitude of the slope that was buried by the lavas. The Quaternary rocks show no signs of structural deformation. 


\section{MINERAL RESOURCES}

\section{ORE DEPOSITS}

The Mount Baldy primitive area is underlain by more than 3,500 feet of upper Tertiary and Quaternary volcanic rocks, mainly flows and associated pyroclastic rocks which apparently contain no metallic ore deposits. The nearest ore deposits that have been mined are goldsilver veins at Mogollon, N. Mex., about 53 miles southeast of the area. In that area deposits occur in veins along faults in Tertiary volcanic rocks.

No faults of significant extent or displacement were found in the primitive area; nor were any claims, prospect pits, or other signs of mining activity found. Concentrations of visible ore minerals were not found; but to check for possible disseminated ore minerals, representative samples of most of the bedrock units were collected for semiquantitative spectrographic analysis; the results of these analyses are shown in table 1.

Sediments from the four main streams draining the primitive area were also analyzed spectrographically. All samples also were analyzed by chemical methods for their gold content, and the results are shown in the table. The metal content of all the samples is very low and indicates that the possibility of commercial ore deposits in the area is remote.

\section{CONSTRUCTION MATERIAL}

Volcanic cinders are quarried nearby for local use as road metal. The small cinder cone(?) in the north part of the area may be suitable for road metal, but many cinder cones east and north of the primitive area are much larger and more easily accessible.

\section{OTHER MINERAL COMMODITIES}

Sedimentary rocks that yield commodities such as oil, gas, coal, and uranium elsewhere in eastern Arizona either are absent in the Mount Baldy area or are present only at great depth.

No test holes for oil or gas have been drilled in the primitive area, probably because of its volcanic character. Test wells have been drilled about 35 miles north of the area, but none have been productive. Wells about 70 miles north of the area found significant quantities of helium-bearing natural gas in the Coconino Sandstone (Permian) (Heindl, 1952). Thin coal beds of poor quality have been mined for local use about 22 miles west-northwest of the area. The coal beds occur in sedimentary rocks of Late Cretaceous age that may be present at a depth of 2,000 feet or more beneath the surface of the primitive 
area. Exploration for coal at such depths is considered to be uneconomical.

Small deposits of uranium are in the Chinle Formation (Triassic) about 40 miles north-northwest of the area, but regional geologic relations indicate that the Chinle Formation is not beneath the Mount Baldy primitive area. Similarly, other uranium-bearing formations of the Colorado Plateau probably are not beneath the area.

\section{ECONOMIC APPRAISAL}

\section{By JoHs H. Souné, U.S. Bureau of Mines}

This report describes the mineral-occurrence investigations made by the U.S. Bureau of Mines in the Mount Baldy primitive area, Arizona, and on the adjacent part of the Fort Apache Indian Reservation that was set aside by resolution of the Tribal Council of the White Mountain Apache Tribe. This study was limited to a determination of the existence of any mining claims, the status of the mining industry in the area, the mineral production from the area, and a very cursory examination along the northeastern edge of the area. All available records of private or U.S. Government exploration activities in the area were searched for data on mining claims, oil and gas leases, or mineral production. The records and personnel of the U.S. Forest Service, Apache National Forest, Springerville; the U.S. Bureau of Land Management, Phoenix; and the County Recorder of Apache County, St. Johns, were consulted, as were various local residents. Acknowledgment is made of the assistance given by all of these.

TABLE 1.-Chemical composition of samples from

\begin{tabular}{|c|c|c|c|c|c|c|c|c|c|c|c|c|c|c|c|c|c|c|c|}
\hline \multicolumn{20}{|c|}{$\begin{array}{l}\text { Semiquantitative spectrographic analyses } \\
\text { (parts per million) }\end{array}$} \\
\hline & Na & $\mathrm{x}$ & $\mathrm{Ti}$ & 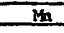 & $\mathrm{Ba}$ & $\mathrm{Be}$ & C & $\mathrm{Ce} \mathrm{C}_{0}$ & $\mathrm{Q}_{\mathrm{C}}$ & ${ }_{15} \mathrm{Cu}_{\mathrm{Ga}}$ & La & $\overline{y o}_{0}$ & $\mathrm{Nb}$ & $\mathrm{Ni} / \mathrm{Pb}$ & Sra & sr & $y$ & $\mathrm{Yb} \quad \mathrm{Zr}$ & $\mathrm{Nd}$ \\
\hline $\begin{array}{l}M B-2 \\
M B-4 \\
M B-6 \\
M B-7 \\
M B-9\end{array}$ & $\begin{array}{l}30,000 \\
30,000 \\
30,000 \\
30,000 \\
30,000\end{array}$ & $\begin{array}{l}30,000 \\
30,000 \\
30,000 \\
50,000 \\
50,000\end{array}$ & $\begin{array}{l}2,000 \\
2,000 \\
5,000 \\
2,000 \\
5,000\end{array}$ & $\begin{array}{r}500 \\
700 \\
700 \\
700 \\
1,000\end{array}$ & $\begin{array}{r}500 \\
500 \\
1,000 \\
70 \\
1,500\end{array}$ & $\begin{array}{l}3 \\
5 \\
2 \\
3 \\
2\end{array}$ & $\begin{array}{rr}3 & 0 \\
5 & 0 \\
2 & 0 \\
3 & 100 \\
2 & 100\end{array}$ & $\begin{array}{ll}0 & 0 \\
0 & 0 \\
0 & 5 \\
0 & 0 \\
0 & 5\end{array}$ & $\begin{array}{ll}0 & 0 \\
0 & 0 \\
5 & 0 \\
0 & 0 \\
5 & 0\end{array}$ & $\begin{array}{rrr}0 & 7 & 30 \\
0 & 5 & 30 \\
0 & 10 & 20 \\
0 & 10 & 30 \\
0 & 7 & 30\end{array}$ & $\begin{array}{r}70 \\
70 \\
70 \\
100 \\
100\end{array}$ & $\begin{array}{l}5 \\
0 \\
5 \\
7 \\
0\end{array}$ & $\begin{array}{r}70 \\
100 \\
50 \\
50 \\
70\end{array}$ & $\begin{array}{ll}5 & 10 \\
0 & 20 \\
0 & 10 \\
0 & 15 \\
0 & 10\end{array}$ & $\begin{array}{r}5 \\
5 \\
7 \\
0 \\
10\end{array}$ & $\begin{array}{l}200 \\
200 \\
300 \\
200 \\
500\end{array}$ & $\begin{array}{ll}15 & 50 \\
10 & 50 \\
50 & 30 \\
15 & 20 \\
30 & 30\end{array}$ & $\begin{array}{ll}3 & 300 \\
5 & 200 \\
3 & 300 \\
3 & 200 \\
3 & 300\end{array}$ & $\begin{array}{r}0 \\
0 \\
0 \\
0 \\
100\end{array}$ \\
\hline $\begin{array}{l}M B-14 \\
\text { MB-16 } \\
\text { MB-10 } \\
\text { MB-12 } \\
\text { MB-19 }\end{array}$ & $\begin{array}{l}50,000 \\
30,000 \\
30,000 \\
20,000 \\
30,000\end{array}$ & $\begin{array}{l}50,000 \\
30,000 \\
70,000 \\
30,000 \\
20,000\end{array}$ & $\begin{array}{l}1,500 \\
5,000 \\
2,000 \\
5,000 \\
7,000\end{array}$ & $\begin{array}{r}2,000 \\
700 \\
2,000 \\
700 \\
700\end{array}$ & $\begin{array}{r}30 \\
700 \\
70 \\
1,000 \\
500\end{array}$ & $\begin{array}{l}3 \\
2 \\
3 \\
0 \\
0\end{array}$ & $\begin{array}{ll}3 & 200 \\
2 & 100 \\
3 & 200 \\
0 & 0 \\
0 & 0\end{array}$ & $\begin{array}{rr}0 & 0 \\
0 & 5 \\
0 & 0 \\
0 & 20 \\
0 & 15\end{array}$ & $\begin{array}{rr}0 & 0 \\
5 & 0 \\
0 & 2 \\
0 & 150 \\
5 & 10\end{array}$ & $\begin{array}{rrr}0 & 7 & 30 \\
0 & 7 & 30 \\
2 & 5 & 30 \\
0 & 50 & 20 \\
0 & 20 & 15\end{array}$ & $\begin{array}{r}150 \\
70 \\
150 \\
30 \\
50\end{array}$ & $\begin{array}{l}0 \\
5 \\
5 \\
0 \\
0\end{array}$ & $\begin{array}{r}100 \\
50 \\
70 \\
0 \\
20\end{array}$ & $\begin{array}{rr}0 & 20 \\
0 & 15 \\
0 & 10 \\
50 & 0 \\
15 & 15\end{array}$ & $\begin{array}{r}10 \\
7 \\
15 \\
20 \\
10\end{array}$ & $\begin{array}{r}20 \\
300 \\
70 \\
1,000 \\
700\end{array}$ & $\begin{array}{rl}0 & 70 \\
20 & 20 \\
1070 \\
15020 \\
7020\end{array}$ & $\begin{array}{ll}5 & 300 \\
2 & 100 \\
7 & 300 \\
3 & 150 \\
2 & 100\end{array}$ & $\begin{array}{r}50 \\
0 \\
100 \\
0\end{array}$ \\
\hline $\begin{array}{l}\mathrm{MB}-20 \\
\mathrm{MB}-38 \\
\mathrm{MB}-21 \\
\mathrm{MB}-24 \\
\mathrm{MB}-30\end{array}$ & $\begin{array}{l}15,000 \\
20,000 \\
20,000 \\
20,000 \\
30,000\end{array}$ & $\begin{array}{r}7,000 \\
7,000 \\
15,000 \\
15,000 \\
50,000\end{array}$ & $\begin{array}{r}7,000 \\
7,000 \\
10,000 \\
10,000 \\
3,000\end{array}$ & $\begin{array}{r}1,000 \\
700 \\
700 \\
700 \\
500\end{array}$ & $\begin{array}{r}300 \\
300 \\
200 \\
1,000 \\
1,000\end{array}$ & $\begin{array}{l}0 \\
0 \\
0 \\
0 \\
3\end{array}$ & $\begin{array}{rr}0 & 0 \\
0 & 0 \\
0 & 0 \\
0 & 0 \\
3 & 100\end{array}$ & $\begin{array}{lr}0 & 15 \\
0 & 15 \\
0 & 30 \\
0 & 20 \\
0 & 5\end{array}$ & $\begin{array}{r}50 \\
5 \\
50 \\
0 \\
150 \\
0 \\
5 \\
5\end{array}$ & $\begin{array}{lll}0 & 30 & 20 \\
5 & 20 & 15 \\
0 & 70 & 20 \\
7 & 70 & 30 \\
0 & 7 & 30\end{array}$ & $\begin{array}{r}30 \\
30 \\
20 \\
70 \\
200\end{array}$ & $\begin{array}{l}0 \\
0 \\
0 \\
0 \\
10\end{array}$ & $\begin{array}{l}20 \\
20 \\
15 \\
20 \\
70\end{array}$ & $\begin{array}{rr}25 & 0 \\
5 & 0 \\
30 & 0 \\
15 & 10 \\
0 & 10\end{array}$ & $\begin{array}{r}15 \\
10 \\
20 \\
20 \\
5\end{array}$ & $\begin{array}{l}700 \\
500 \\
700 \\
700 \\
500\end{array}$ & $\begin{array}{rr}100 & 20 \\
70 & 15 \\
200 & 20 \\
200 & 30 \\
50 & 30\end{array}$ & $\begin{array}{rl}2 & 150 \\
2 & 150 \\
<3 & 150 \\
<3 & 150 \\
3 & 150\end{array}$ & 0 \\
\hline $\begin{array}{l}M B-31 \\
M B-36 \\
M B-37 \\
M B-32 \\
M B-33\end{array}$ & $\begin{array}{r}30,000 \\
7,000 \\
30,000 \\
30,000 \\
30,000\end{array}$ & $\begin{array}{l}50,000 \\
10,000 \\
30,000 \\
30,000 \\
30,000\end{array}$ & $\begin{array}{l}5,000 \\
7,000 \\
3,000 \\
5,000 \\
5,000\end{array}$ & $\begin{array}{l}500 \\
700 \\
500 \\
500 \\
700\end{array}$ & $\begin{array}{r}1,000 \\
500 \\
1,000 \\
1,000\end{array}$ & $\begin{array}{r}3 \\
2.5 \\
3 \\
3 \\
1.5\end{array}$ & $\begin{array}{r}3 \\
5 \\
5 \\
300 \\
100 \\
5 \\
500 \\
5\end{array}$ & $\begin{array}{rr}0 & 7 \\
0 & 20 \\
0 & 5 \\
0 & 7 \\
0 & 7\end{array}$ & $\begin{array}{ll}7 & 15 \\
0 & 50 \\
5 & 15 \\
7 & 20 \\
7 & 0\end{array}$ & $\begin{array}{rrr}5 & 7 & 30 \\
0 & 50 & 30 \\
5 & 10 & 30 \\
0 & 15 & 30 \\
0 & 7 & 30\end{array}$ & $\begin{array}{r}100 \\
70 \\
100 \\
70 \\
70\end{array}$ & $\begin{array}{l}0 \\
0 \\
0 \\
0 \\
5\end{array}$ & $\begin{array}{l}50 \\
50 \\
70 \\
30 \\
50\end{array}$ & $\begin{array}{rr}5 & 10 \\
20 & 0 \\
5 & 10 \\
5 & 15 \\
0 & 10\end{array}$ & $\begin{array}{r}7 \\
20 \\
10 \\
7 \\
10\end{array}$ & $\begin{array}{l}300 \\
150 \\
200 \\
300 \\
500\end{array}$ & $\begin{array}{rr}70 & 30 \\
100 & 20 \\
30 & 30 \\
50 & 30 \\
50 & 30\end{array}$ & $\begin{array}{ll}3 & 200 \\
3 & 150 \\
3 & 200 \\
5 & 200 \\
3 & 200\end{array}$ & 0 \\
\hline $\begin{array}{l}B-34 \\
B-35\end{array}$ & $\begin{array}{l}30 \text {, } \\
30 \text {, }\end{array}$ & & 5 & $\begin{array}{l}700 \\
500\end{array}$ & 1 & & 3200 & 1010 & 5 & 01030 & 100 & $\begin{array}{l}0 \\
5\end{array}$ & 70 & 1010 & 10 & $\begin{array}{l}500 \\
300\end{array}$ & 20030 & $\begin{array}{l}3150 \\
3200\end{array}$ & 0 \\
\hline
\end{tabular}

[Semiquantitative spectrographic analyses by Harriet G. Neiman; chemical analyses, 


\section{MINERAL APPRAISAL}

According to the records of the Bureau of Land Management, there are no patented mining claims within the Mount Baldy primitive area. Apache County records were consulted for evidence of unpatented mining claims; but without prior knowledge of claim names and claimants, it is virtually impossible to obtain useful information in this way. There are no established mining districts, and the system of claim filing does not permit compilation of recorded claims by area. However, discussions with personnel of the U.S. Forest Service and the Apache County Recorder's Office indicate that there are no unpatented claims in the primitive area. Local residents who were interviewed had no knowledge of mining operations, past or present, in the area; and neither Arizona nor Federal records show any production. Thus, although it is remotely possible that claims not identified in the records as to actual location could exist within the primitive area, the lack of any awareness locally of such activities or any other corroborating evidence makes the possibility unlikely. No attempt was made to check the possible existence of any private land holdings of nonmineral character in the area.

A cursory field examination of the Mount Baldy primitive area indicates that the entire terrain consists largely of fairly recent volcanic rocks. The absence of past or present mining or claim-locating activity and of mineral production indicates that the mineral potential of the area is negligible. Nothing was observed in the field to alter this conclusion.

\section{the Mount Baldy primitive area and vicinity}

\begin{tabular}{|c|c|c|c|c|c|c|c|}
\hline $\begin{array}{l}\text { Sample } \\
\text { No. }\end{array}$ & S1 & $\begin{array}{r}\text { an } \\
\text { an } \\
\mathrm{Al} \\
\end{array}$ & $\begin{array}{l}\text { ive } 8 \\
\text { - Con } \\
\text { (per } \\
\mathrm{Fe}\end{array}$ & $\begin{array}{l}\text { trogr } \\
\text { ued. } \\
\text { t) } \\
\mathrm{Mg}\end{array}$ & $\mathrm{Ca}$ & $\begin{array}{l}\text { Chemical analyses } \\
\text { (parts per million) } \\
\text { Au }\end{array}$ & Sample description. \\
\hline $\begin{array}{l}M B-2 \\
M B-4 \\
M B-6 \\
M B-7 \\
M B-9\end{array}$ & $\begin{array}{l}>10 \\
>10 \\
>10 \\
>10 \\
>10\end{array}$ & $\begin{array}{l}>10 \\
>10 \\
>10 \\
>10 \\
>10\end{array}$ & $\begin{array}{l}3 \\
3 \\
5 \\
2 \\
3\end{array}$ & $\begin{array}{l}.5 \\
.5 \\
.7 \\
.5 \\
.3\end{array}$ & $\stackrel{1}{1}_{1}^{* 7}$ & $\begin{array}{l}<.1 \\
<.1 \\
<.1 \\
<.1 \\
<.1\end{array}$ & $\begin{array}{l}\text { Andesite. } \\
\text { Do. } \\
\text { Do. } \\
\text { Do. } \\
\text { Do. }\end{array}$ \\
\hline $\begin{array}{l}M B-14 \\
M B-16 \\
M B-10 \\
M B-12 \\
M B-19\end{array}$ & $\begin{array}{l}>10 \\
>10 \\
>10 \\
>10 \\
>10\end{array}$ & $\begin{array}{r}>10 \\
>10 \\
>10 \\
>10 \\
7\end{array}$ & $\begin{array}{l}2 \\
3 \\
2 \\
7 \\
7\end{array}$ & $\begin{array}{l}.15 \\
1^{.5} \\
3 \\
1.5\end{array}$ & $\begin{array}{l}.2 \\
1.5 \\
5 \\
3\end{array}$ & $\begin{array}{l}<.1 \\
<.1 \\
<.1 \\
<.1 \\
<.1\end{array}$ & $\begin{array}{l}\text { Do. } \\
\text { Do. } \\
\text { Conglonerate, volcanic stones. } \\
\text { Do. } \\
\text { Basaltic Bandstone. }\end{array}$ \\
\hline $\begin{array}{l}\mathrm{MB}-20 \\
\mathrm{MB}-38 \\
\mathrm{MB}-21 \\
\mathrm{MB}-24 \\
\mathrm{MB}-30\end{array}$ & $\begin{array}{l}>10 \\
>10 \\
>10 \\
>10 \\
>10\end{array}$ & $\begin{array}{r}>10 \\
7 \\
>10 \\
>10 \\
>10\end{array}$ & $\begin{array}{r}7 \\
7 \\
>10 \\
>10 \\
3\end{array}$ & $\begin{array}{l}3 \\
2 \\
5 \\
3 \\
.5\end{array}$ & $\begin{array}{l}5 \\
3 \\
7 \\
5 \\
1\end{array}$ & $\begin{array}{l}<.1 \\
<.1 \\
<.1 \\
<.1 \\
<.1\end{array}$ & $\begin{array}{l}\text { Do. } \\
\text { Do. } \\
\text { Vesicular basalt. } \\
\text { Do. } \\
\text { Andesite }\end{array}$ \\
\hline $\begin{array}{l}\mathrm{MB}-31 \\
\mathrm{MB}-36 \\
\mathrm{MB}-37 \\
\mathrm{MB}-32 \\
\mathrm{MB}-33\end{array}$ & $\begin{array}{l}>10 \\
>10 \\
>10 \\
>10 \\
>10\end{array}$ & $\begin{array}{r}>10 \\
7 \\
>10 \\
>10 \\
>10\end{array}$ & $\begin{array}{l}5 \\
7 \\
3 \\
3 \\
3\end{array}$ & $\begin{array}{r}.5 \\
1.5 \\
.5 \\
.5\end{array}$ & $\begin{array}{r}.7 \\
.7 \\
.7 \\
.7 \\
1.5\end{array}$ & $\begin{array}{l}<.1 \\
<.1 \\
<.1 \\
<.1 \\
<.1\end{array}$ & $\begin{array}{l}\text { Outwash sandstone. } \\
\text { Do. } \\
\text { Outwash clay. } \\
\text { Stream sediment. } \\
\text { Do. }\end{array}$ \\
\hline $\begin{array}{l}M B-34 \\
M B-35\end{array}$ & $\begin{array}{l}>10 \\
>10\end{array}$ & $\begin{array}{l}>10 \\
>10\end{array}$ & $\begin{array}{l}2 \\
5\end{array}$ & .5 & $\begin{array}{l}1 \\
1\end{array}$ & $\begin{array}{l}<.1 \\
<.1\end{array}$ & $\begin{array}{l}\text { Do. } \\
\text { Do. }\end{array}$ \\
\hline
\end{tabular}

all <0.1 ppm, by Kam W. Leong, Harry Nakagawa, Ted Romer, and Art Hubert] 
The Mount Baldy area is the center of an extensive late volcanic field extending many miles in all directions. Because of this, the mineral potential of the adjoining areas is assumed to be similar to that of the primitive area.

The area is remote from established mining districts. The Pinedale mining district (coal) is about 50 miles to the northwest. The Granville district (silver) is about 50 miles south of Mount Baldy; and this district is a few miles north of the Copper King Mountain (Metcalf) and the Copper Mountain (Morenci) districts, large districts with copper as the major economic metal. The Mogollon mining district (silver) in New Mexico is about 50 miles to the southeast.

\section{REFERENCES CITED}

Darton, N. H., 1925, A résumé of Arizona geology : Arizona Univ., Arizona Bur. Mines Bull. 119, geol. ser, 3, 298 p.

Gilbert, G. K., 1875, Geology of portions of New Mexico and Arizona, explored and surveyed in 1873: U.S. Geog. and Geol. Surveys west of the 100th Meridian (Wheeler), v. 3, p. 505-572.

Heindl, L. A., 1952, Occurrence of helium in northeastern Arizona [abs.] : Geol. Soc. America Bull., v. 63, no. 12, p. 1331.

Melton, M. A., 1961, Multiple Pleistocene glaciation of the White Mountains, Apache County, Arizona: Geol. Soc. America Bull., v. 72, no. 8, p. 1279-1281.

Reagan, A. B., 1903, Geology of the Fort Apache region in Arizona: Am. Geologist, v. 32, no. 5, p. 265-308.

Wilson, E. D., Moore, R. T., and O'Haire, R. T., 1960, Geologic map of Narajo and Apache Counties, Arizona: Tucson, Arizona Bur. Mines, scale 1:375,000 (about 1 in. to 6 mi.).

Wrucke, C. T., 1961, Paleozoic and Cenozoic rocks in the Alpine-Nutrioso area, Apache County, Arizona : U.S. Geol. Survey Bull. 1121-H, p. H1-F26. 


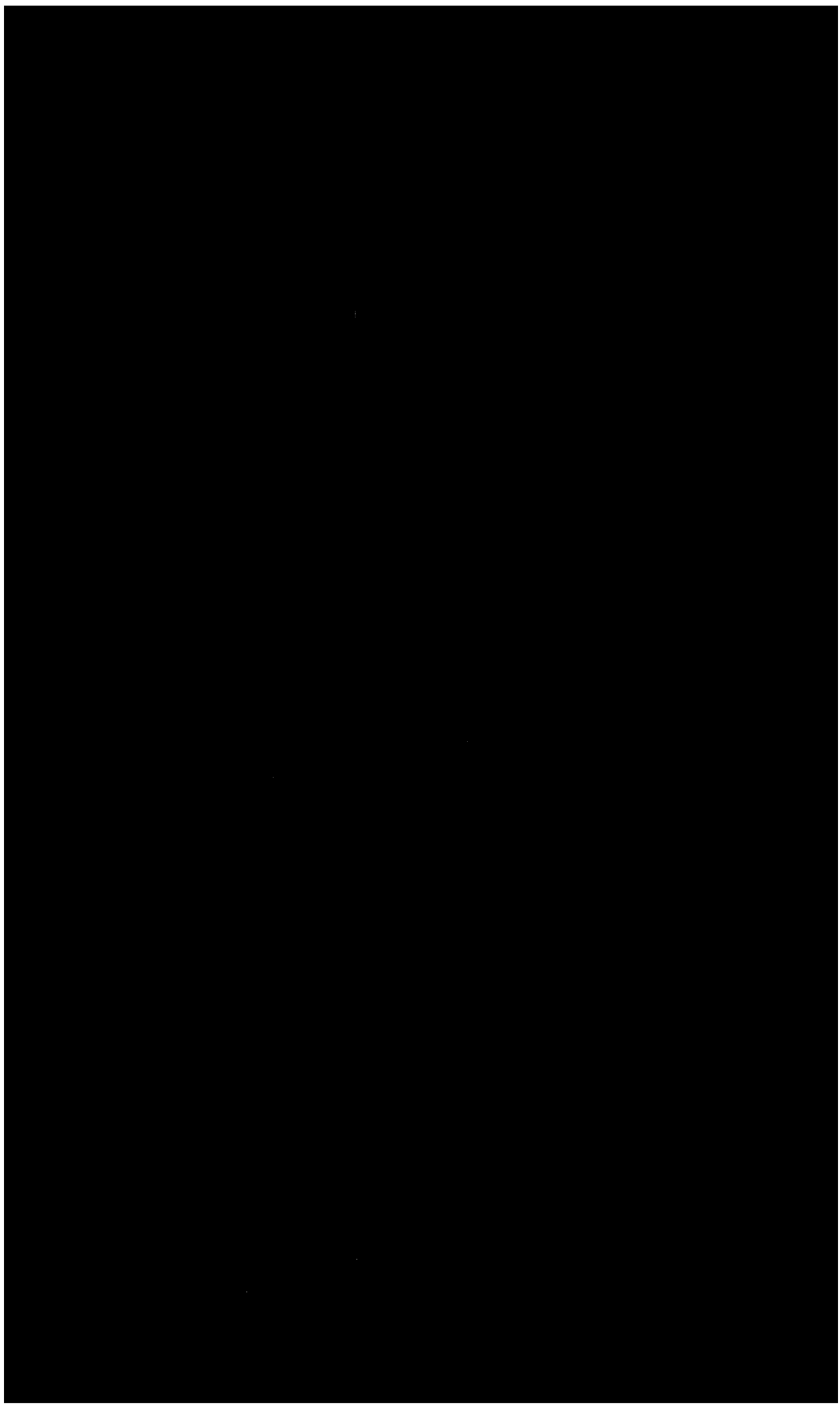




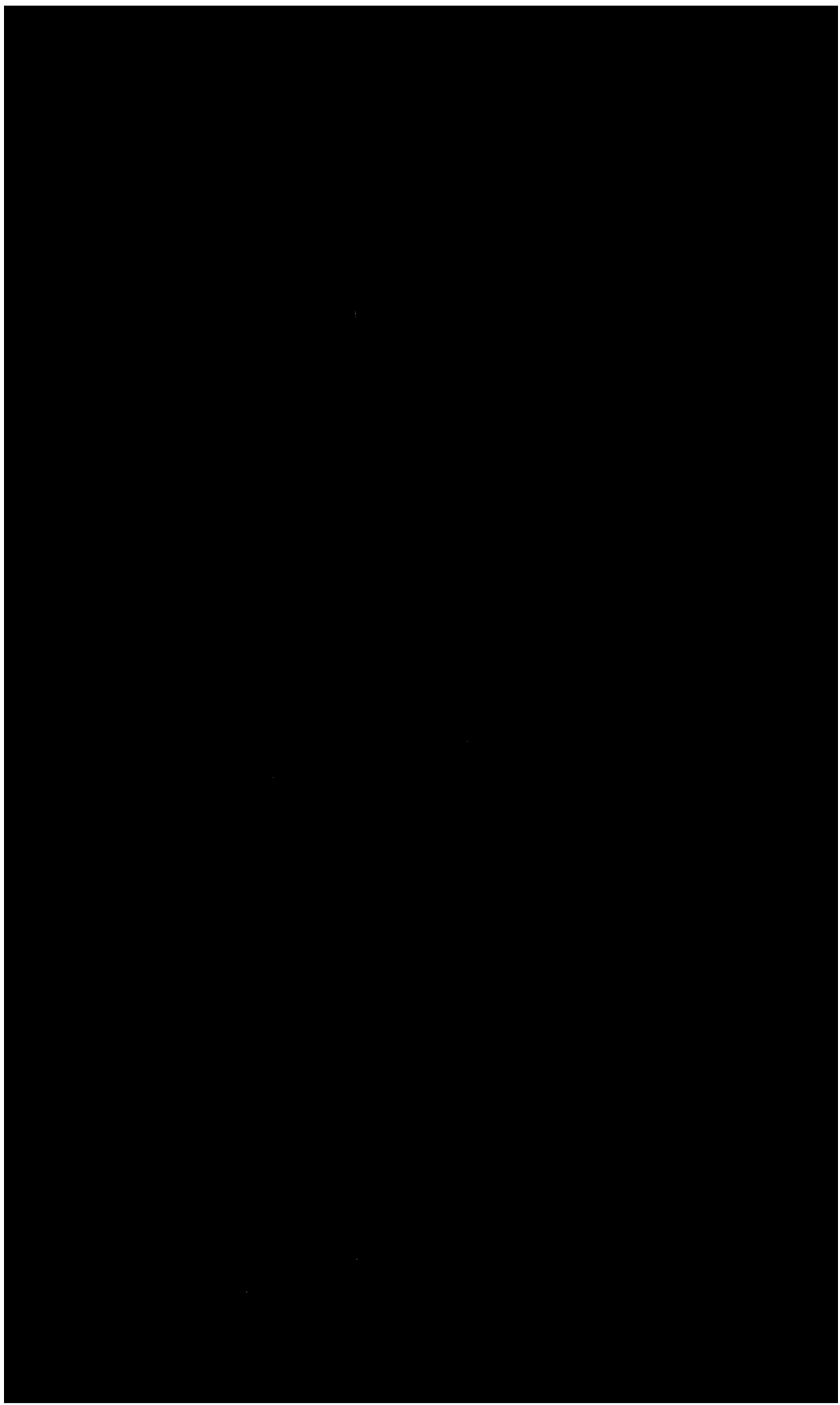

